Jurnal Penelitian Bahasa dan Sastra Indonesia V2.i2 (61-71)

\title{
SARKASME Dalam LIRIK LAGU DANGDUT KEKINIAN (KAJIAN SEMANTIK)
}

\author{
Putri Dian Afrinda \\ Dosen Program Studi Pendidikan Bahasa dan Sastra Indonesia \\ STKIP PGRI Sumatera Barat \\ putridian_afrinda@yahoo.com \\ putri@stkip-pgri-sumbar.ac.id \\ Submitted :28-09-2016, Reviewed:06-10-2016, Accepted:08-2-2017 \\ http://dx.doi.org/10.22202/JG.2016.v2i2.1040
}

\begin{abstract}
This paper contains a discussion of diction contained in the present dangdut song lyrics. This discussion is based on the view that the diction is the choice of words indicates the intention or things that will be addressed. Diction or choice of words is important in communication, both oral and written. Diction on the lyrics of the song is delivering a message. If the intent that the speaker or writer is different from that addressed the listener or reader, the diction used means less precise, so ambiguous. Creativity choice of words used in the song lyrics, also represents the meaning of the song. This paper will outline the changes in the manifold meanings of sarcasm in the lyrics on dangdut music streams present or present. Songs can generally be enjoyed by all people. Starting from the older generation and young adults to children. If the song is heard not according to age, then this can indirectly destroy the character of the child. To shape the character starts in the womb of the mother. The baby already played classical music to stimulate the motor so that the baby is more active. Because classical music is considered similar to the mother's heartbeat. The song is currently developing prefers cool music playing, lyrics are catchy, compared diction that animates the song. This resulted in the song less useful or meaningful to the listener. If just a favor to be heard, then a song will be the loss of life because it is not meaningful. Song or chant, not only as a means of entertainment, but there is no intention to be delivered by the composer.
\end{abstract}

Keywords: Sarcasm, lyrics, Semantics

\begin{abstract}
Abstrak
Tulisan ini berisi pembahasan tentang diksi yang terdapat pada lirik lagu dangdut kekinian. Pembahasan ini dilandasi pandangan bahwa diksi merupakan pilihan kata yang menunjukkan maksud atau hal yang akan ditujukan. Diksi atau pilihan kata sangat berperan dalam komunikasi, baik lisan, maupun tulisan. Diksi pada lirik lagu merupakan penyampaian pesan. Jika maksud yang disampaikan pembicara ataupun penulis berbeda dengan yang ditanggapi pendengar atau pembaca, maka diksi yang digunakan berarti kurang tepat, sehingga bermakna ganda. Kreativitas pilihan kata yang digunakan pada lirik lagu, juga mewakili makna dari lagu tersebut. Tulisan ini akan menguraikan perubahan makna yang berjenis sarkasme dalam lirik lagu pada aliran musik dangdut masa kini atau kekinian. Lagu pada umumnya dapat dinikmati oleh semua kalangan. Mulai dari generasi tua, muda, dewasa hingga anak-anak. Jika lagu yang didengar tidak sesuai dengan umurnya, maka hal ini secara tidak langsung dapat menghancurkan karakter anak. Untuk membentuk karakter anak dimulai sejak dalam kandungan ibu. Calon bayi sudah diperdengarkan musik-musik klasik untuk merangsang motorik sehingga bayi lebih aktif bergerak. Karena musik klasik dianggap mirip dengan detak jantung sang ibu. Lagu yang berkembang saat ini lebih mengutamakan musik yang asyik diputar, lirik lagu yang mudah diingat, dibandingkan diksi yang menjiwai lagu tersebut. Hal ini mengakibatkan lagu tersebut kurang bermanfaat atau bermakna bagi pendengar. Jika hanya sekedar nikmat untuk didengar, maka sebuah lagu tersebut akan kehilangan
\end{abstract}


Jurnal Penelitian Bahasa dan Sastra Indonesia V2.i2 (61-71)

jiwa karena tidak bermakna. Lagu atau nyanyian, tidak hanya sebagai sarana hiburan, tetapi ada maksud yang hendak disampaikan oleh pencipta lagu.

\section{Kata Kunci: Sarkasme, Lirik Lagu, Semantik}

\section{PENDAHULUAN}

Penelitian ini didasari atas pengamatan dan pemikiran tentang pembentukan karakter anak dimulai dari dalam kandungan. Hal ini dapat dibuktikan dengan seorang ibu yang memperdengarkan musik pada janinnya melalui perut. Secara tidak langsung, seorang ibu sudah mulai membentuk karakter anak. Istilah karakter memiliki kedekatan dan titik singgung dengan etika. Karena umumnya orang yang dianggap memiliki karakter yang baik setelah mampu bertindak berdasarkan etika yang berlaku di tengah-tengah masyarakat.

Karakter dimaknai sebagai cara berpikir dan yang berprilaku yang khas tiap individu untuk hidup dan bekerja sama, baik dalam lingkup keluarga, masyarakat, bangsa, dan negara. mendefinisikan karakter sebagai atribut atau ciri-ciri yang membentuk dan membedakan ciri pribadi, ciri etis, dan kompleksitas mental dari seseorang, suatu kelompok atau bangsa. Karakter merupakan nilai dan dasar prilaku yang menjadi acuan tata nilai interaksi antar manusia. Secara universal berbagai karakter dirumuskan sebagai nilai hidup bersama berdasarkan atas pilar: kedamaian, menghargai, kerja sama, kebebasan, kebahagiaan, kejujuran, kerendahan hati, kasih sayang, tanggung jawab, kesederhanaan, toleransi, dan persatuan.

Karakter dapat dibentuk dengan berbagai cara seperti dengan memberikan contoh atau tindakan langsung maupun melalui media misalnya media lagu. Mengapa lagu dapat membentuk karakter seseorang? Karena pesan yang terdapat dalam lagu akan mudah diingat anak dengan dinyanyikan. Mengingat begitu pentingnya pesan dalam lagu tersebut, maka pilihan kata atau diksi perlu mendapat perhatian. Diksi-diksi dalam lirik tersebut jika tidak mudah dicerna anak, tentu anak akan mencari informasi yang terkait dengan diksi yang ingin diketahuinya. Fenomena yang terjadi saat ini adalah orang yang menciptakan lagu tidak lagi memperhatikan diksi, tetapi lebih mengutamakan irama dan musik yang asyik dan mudah diingat. Diksi pada lirik lagu dangdut kekinian terjadi peubahan makna dengan jenis sarkasme. Jika lagu yang didengar tidak sesuai dengan usia anak, maka hal ini secara tidak langsung dengan mudahnya dapat menghancurkan karakter anak yang sudah dibentuk tersebut.

Lagu sebagai media perlu menempatkan dirinya sebagai pendidik secara simultan ikut memberi pengaruh terhadap proses pembentukan karakter anak-anak dan remaja. Apalagi pada era globalisasi seperti saat ini, guru dan sekolah menghadapi tantangan pola pergaulan global peserta didik yang hampir tidak dapat dikendalikan dan dikenali. Penggunaan sistem informasi berteknologi tinggi melalui jaringan internet telah memungkinkan anak menggunakan sebagian waktunya untuk mengakses informasinya sendiri, memberi peluang 
Jurnal Penelitian Bahasa dan Sastra Indonesia V2.i2 (61-71)

bagi anak memperoleh informasi tanpa seleksi. Untuk itu diperlukan juga sebuah regulasi dalam pemanfaatan internet agar bisa berfungsi edukasi, bukan sebaliknya bersifat deskruktif terhadap perkembangan karakter atau moral anak-anak dan remaja.

Pendidikan karakter semata-mata merupakan bagian dari pembelajaran yang baik dan merupakan bagian yang fundamental dan pendidikan yang baik. Pendidikan karakter sebagai upaya yang sungguh-sungguh untuk membantu seseorang memahami, peduli, dan bertindak dengan landasan inti nilai-nilai etis. Pendidikan karakter dapat pula dimaknai sebagai upaya yang terencana untuk menjadikan peserta didik mengenal, peduli, dan menginternalisasi nilai-nilai sehingga peserta didik berperilaku sebagai insan kamil. Pendidikan karakter juga dapat dimaknai sebagai suatu sistem penamaan nilai-nilai karakter kepada warga sekolah yang meliputi komponen pengetahuan, kesadaran atau kemauan dan tindakan untuk melaksanakan nilai-nilai tersebut baik terhadap Tuhan YME, diri sendiri, sesama, lingkungan, maupun kebangsaan sehingga menjadi manusia insan kamil.

Jadi pendidikan karakter adalah proses pemberian tuntunan kepada peserta didik untuk menjadi manusia seutuhnya yang berkarakter dalam dimensi hati, pikir, raga, serta rasa dan karsa. Pendidikan karakter dapat dimaknai sebagai pendidikan nilai, pendidikan budi pekerti, pendidikan moral, pendidikan watak yang bertujuan mengembangkan kemampuan peserta didik untuk memberikan keputusan baikburuk, memelihara apa yang baik, dan mewujudkan kebaikan itu dalam kehidupan sehari-hari.

Karakter yang identik dengan nilai, etika dalam mewujudkan kebaikan akan beralih menjadi proses penghancuran karakter karena terdapat perubahan makna. Perubahan makna itu dapat berupa perubahan konsep dan atau perubahan nilai rasa. Contoh perubahan makna yang berkaitan dengan konsep adalah berubahnya makna leksem tangan dari kata umum menjadi istilah. Tangan sebagai kata umum bermakna 'bagian tubuh mulai dari pangkal ketiak sampai dengan ujung jari' sedangkan tangan sebagai istilah dibidang kedokteran bermakna 'bagian tubuh mulai dari pergelangan tangan sampai dengan ujung jari'.

Menurut Manaf (2008:126) perubahan makna dapat berupa perubahan konsep dan atau perubahan nilai rasa. Perubahan makna menurut Parera (2004:107) adalah gejala pergantian rujukan dari simbol bunyi yang sama. Ini berarti dalam konsep perubahan makna terjadi pergantian rujukan yang berbeda dari rujukan semula.

Perubahan makna ini dapat mencakupi makna kognitifnya dan makna emotifnya. Makna kognitif ini berkaitan dengan makna konseptual suatu leksem dan makna emotof berkaitan dengan nilai rasa suatu leksem. Berkaitan dengan makna konseptual suatu leksem atau satuan leksikal, dapat dilihat kedudukan leksem yang maknanya berubah dalam kontek medan makna. Dalam konteks medan makna, perubahan makna dapat bersifat meluas, menyempit, atau berubah total. Dalam konteks nilai rasa, perubahan 
Jurnal Penelitian Bahasa dan Sastra Indonesia V2.i2 (61-71)

makna dapat bersifat menghalus, mengasar, mengindah, dan mengonkrit atau menegas.

Jenis perubahan yang akan dikaji pada penelitian ini adalah perubahan makna dengan jenis sarkasme. Kata sarkasme berasal dari bahasa Yunani sarkasmos yang diturunkan dari kata kerja sakasein yang berarti 'merobek-robek daging seperti anjing', 'menggigit bibir karena marah' atau 'bicara dengan kepahitan'. Bila dibandingkan dengan ironi dan sinisme, maka sarkasme ini lebih kasar. Sarkasme adalah sejenis karya bahasa yang mengandung 'olok-olok atau sindiran pedas dan menyakiti hati'.

Sarkasme merupakan suatu acuan yang lebih kaar dari ironi dan sinisme. Ia adalah suatu acuan yang mengandung kepahitan dan celaan yang getir. Sarkasme dapat saja bersifat ironos, dapat juga tidak, tetapi yang jelas adalah bahwa gaya ini selalu akan menyakiti hati dan kurang enak didengar. Kata sarkasme diturunkan dari kata Yunani sarkasmos, yang lebih jauh diturunkan dari kata kerja sakasein yang berarti "merobek-robek daging seperti anjing", "menggigit bibir karena marah", atau "berbicara dengan kepahaman".

Mengasar adalah perubahan makna yang berupa leksem yang semula dirasakan halus kemudian karena faktor tertentu, makna leksem atau satuan leksikal itu dirasakan kasar. Contoh, dahulu kata perempuan mempu-nyai nilai rasa halus dan berprestise. Sekarang, kata perempuan itu diganti dengan wanita. Pengasaran adalah usaha untuk mengganti kata yang maknanya halus atau bermakna biasa dengan kata yang maknanya kasar. Usaha atau gejala pengasaran ini biasa dilakukan orang dalam situasi yang tidak ramah atau untuk menunjukkan kejengkelan. Misalnya, ungkapan masuk kotak dipakai untuk mengganti kata kalah. Namun ada pula kata yang sebenarnya bernilai kasar, tetapi sengaja digunakan untuk lebih memberi tekanan tanpa terasa kekasarannya. Misalnya, kata mencuri dipakai dalam kalimat "Persib berhasil mencuri satu gol dari Persija". Padahal, sebenarnya perbuatan mencuri adalah suatu tindakan kegiatan yang dapat diancam dengan hukuman penjara.

Berdasarkan jabaran penjelasan di atas, jelaslah bahwa pentingnya pilihan kata gar tidak terjadi perubahan makna yang kasar atau dalam hal ini diberi istilah sarkasme, dapat mengakibatkan kehancuran karakter khususnya pada anak-anak. Lagu dangdut kekinian sudah menjadi konsumsi publik termasuk anak-anak.

\section{METODE PENELITIAN}

Penelitian ini menerapkan metode kualitatif deskriptif. Data yang dikumpulkan berupa kata-kata, gambar dan bukan angka-angka. Penelitian ini akan berisi kutipan-kutipan data untuk memberi gambaran penyajian pada penelitian. Data pada penelitian ini adalah tujuh lirik lagu dangdut yang sesuai dengan salah satu jenis perubahan makna pada kajian semantik yaitu sarkasme. Tujuh lirik lagu dangdut tersebut dapat disebut sebagai dokumen. Teknik yang digunakan untuk menganalisis dokumen adalah analisis isi (content analysis). Kajian isi adalah teknik apa pun yang digunakan untuk menarik kesimpulan melalui usaha menemukan karakteristik 
Jurnal Penelitian Bahasa dan Sastra Indonesia V2.i2 (61-71)

pesan, dan dilakukan secara objektif dan sistematis. Pengumpulan data dilakukan dengan cara mencatat kembali lirik lagu yang didengar dari alat pemutar musik.

\section{HASIL DAN PEMBAHASAN}

Penelitian ini akan membahas lirik lagu dangdut kekinian ditinjau dari dua kajian teori. Teori yang pertama adalah pendidikan karakter dan teori yang kedua yaitu tentang perubahan makna pada kajian semantik. Pembahasan data sesuai dengan indikator dari kedua teori tersebut. Indikator pertama, pendidikan karakter dilihat dari aspek rasa, karsa, moral dan budi pekerti. Indikator kedua, perubahan makna dapat berupa perubahan konsep dan atau perubahan nilai rasa, sindiran pedas, olok-olok, menyakiti hati, kurang enak didengar serta mengganti kata yang maknanya halus atau bermakna biasa dengan kata yang maknanya kasar. Data di bawah ini diambil dari lirik lagu yang dinyanyikan oleh Cita Citata dengan judul Perawan atau Janda, Zaskia Gotik dengan judul Bang Ojek dan Sisa Semalam, kemudian Siti Badriah dengan judul Berondong Tua dan Ketagihan, Linda Moy Moy dengan judul Gadis Bukan Perawan serta Juwita Bahar dengan judul lagu Buka Sikit Joss. Berikut akan dijelaskan satu-persatu.

Judul lagu: Perawan atau Janda

Penyanyi : Cita-citata

Abang pilih yang mana

perawan atau janda

Perawan memang menawan, janda lebih menggoda
Diksi pada lirik lagu di atas terjadi perubahan makna pada kata menggoda. Kata menggoda termasuk sarkasme karena sesuai dengan karakteristik sarkasme yaitu kurang enak didengar dan menyakiti hati. Hal ini sejalan dengan Sugono dkk (2008: 456) kata goda berarti ajak berbuat dosa atau mengganggu. Menggoda berarti mengajak (menarik-narik hati) supaya berbuat dosa atau berbuat jahat. Dari uraian tersebut jelaslah bahwa diksi menggoda kurang tepat digunakan pada lirik tersebut. Pendidikan karakter yang hancur karena kata tersebut adalah nilai rasa, karsa, moral dan budi perkerti. Keempat indikator pada pendidikan karakter ini ditinjau dari segi baik buruknya sikap, tingkah laku ataupun mengenai perbuatan.

\section{Abang pilih yang mana perawan atau janda Perawan memang cantik, janda lebih menarik Kalau abang pilih perawan Masih muda masih segelan}

Diksi pada lirik lagu di atas terjadi perubahan makna pada kata segelan. Kata menggoda termasuk segelan karena sesuai dengan karakteristik sarkasme yaitu bersifat olok-olok dan merupakan sindiran pedas. Karena segel menyangkut pada suatu benda baru dalam kemasan plastik yang terbungkus rapi. Hal ini sejalan dengan Sugono dkk (2008: 1240) kata segel berarti cap, meterai. Segelan berarti sesuatu yang disegel. Kata tersebut kurang kurang tepat digunakan karena menunjukkan perilaku menyamakan manusia dengan benda mati. Jika benda baru ditunjukkan dengan plastik atau kemasan yang belum dibuka, maka manusia khususnya wanita diibaratkan pada selaput dara yang masih utuh, yang belum terbuka atau robek. Pendidikan karakter yang hancur karena kata tersebut adalah nilai rasa, karsa, moral dan budi 
Jurnal Penelitian Bahasa dan Sastra Indonesia V2.i2 (61-71)

perkerti. Keempat indikator pada pendidikan karakter ini ditinjau dari segi baik buruknya sikap, tingkah laku ataupun mengenai perbuatan. Baik buruknya perbuatan seorang wanita, dapat dilihat dari segel yang masih utuh.

Belum disentuh orang

belum berpengalaman

Diksi pada lirik lagu di atas terjadi perubahan makna pada frasa belum berpengalaman. Makna belum berpengalaman di sini seperti seseorang yang sudah banyak pengetahuan dan banyak hal yang telah dialaminya. Frasa belum berpengalaman termasuk sarkasme karena sesuai dengan karakteristik sarkasme yaitu kurang enak didengar dan menyakiti hati. Hal ini sejalan dengan Sugono dkk (2008: 34-35) kata alam, mengalami berarti merasai (menjalani, menanggung) suatu peristiwa. Berpengalaman berarti mempunyai pengalaman, telah banyak pengalaman. Dari uraian tersebut jelaslah bahwa frasa belum berpengalaman kurang tepat digunakan pada lirik tersebut. Belum berpengalaman jika dilihat pada larik sebelumnya yaitu belum disentuh orang bermakna pengalaman dengan pasangan lawan jenis. Pendidikan karakter yang hancur karena frasa tersebut adalah nilai rasa, karsa, moral dan budi perkerti. Keempat indikator pada pendidikan karakter ini ditinjau dari segi baik buruknya sikap, tingkah laku ataupun mengenai perbuatan.

Kalau abang pilih janda

Sudah pasti lebih dewasa

Sudah bermain cinta

Banyak pengalamannya

Abang pilih yang mana

perawan atau janda

Perawan memang bohai

janda lebih aduhai
Diksi pada lirik lagu di atas terjadi perubahan makna pada frasa sudah bermain cinta. Frasa sudah bermain cinta termasuk sarkasme karena berdasarkan karakteristik sarkasme yaitu kurang enak didengar, terdapat sindiran pedas, makna olok-olok dan menyakiti hati. Perubahan makna yang halus menjadi kasar tersebut Hal ini sejalan dengan Sugono dkk (2008: 268) cinta berarti suka sekali, sayang benar. Bermain berarti melakukan sesuatu untuk bersenang-senang. Kata tersebut tidak cocok digunakan karena menunjukkan perilaku seseorang yang suka melakukan perbuatan atau sesuatu dengan pasangan untuk bersenang-senang. Dari uraian tersebut jelaslah bahwa frasa sudah bermain cinta kurang tepat digunakan pada lirik tersebut. Pendidikan karakter yang hancur karena kata tersebut adalah nilai rasa, karsa, moral dan budi perkerti. Keempat indikator pada pendidikan karakter ini ditinjau dari segi baik buruknya sikap, tingkah laku ataupun mengenai perbuatan.

Judul lagu: Bang Ojek

Penyanyi : Zaskia Gotik

bang ojek, bang ojek gak sabar nungguin abang gak pake lama-lama ya bang aku tunggu di depan gang bang ojek, bang ojek gak bosan naikin abang jangan lupa pengamannya bang biar nanti neneng tenang ayo bang jalan lihat ke depan abang fokus megangin setang jangan lirik belakang di gas terus bang, waspada lobang biar eneng selamat sampai tujuan bang, bang ojek sayang bang, eneng sayang abang bang, bang ojek sayang 
Jurnal Penelitian Bahasa dan Sastra Indonesia V2.i2 (61-71)

Diksi pada lirik lagu di atas terjadi perubahan makna pada klausa naikin abang, jangan lupa pengamannya bang, biar nanti neneng tenang. Klausa tersebut termasuk sarkasme karena sesuai dengan karakteristik sarkasme yaitu kurang enak didengar, olok-olok dan menyakiti hati. Hal ini sejalan dengan Sugono dkk (2008: 949) kata naik berarti mendaki, memanjat, dan menunggangi. Selajutnya Sugono dkk (2008: 46-47) kata aman berarti bebas dari bahaya, pengaman berarti alat untuk menghindarkan atau mencegah terjadinya kecelakaan. Naikin abang, pengamannya bang berarti memanjat si abang dengan menggunakan alat untuk mencegah terjadinya hal yang tidak diinginkan. Sebetulnya yang dimaksud pada lirik lagu tersebut menaiki ojek punya si abang dengan memakai pengaman berupa helm.

Tetapi karena diksi tersebut tidak lengkap atau ada yang hilang, maka maknanya pun berubah menjadi sarkasme, karena menyamakan sifat benda dengan manusia. Dari uraian tersebut jelaslah bahwa diksi naikin abang, jangan lupa pengamannya bang kurang tepat digunakan pada lirik tersebut. Pendidikan karakter yang hancur karena kata tersebut adalah nilai rasa, karsa, moral dan budi perkerti. Keempat indikator pada pendidikan karakter ini ditinjau dari segi baik buruknya sikap, tingkah laku ataupun mengenai perbuatan.

Judul lagu: Keenakan

Penyanyi : Siti Badriah

pacarku sudah ada selusin

sejak aku sama kamu diputusin

ternyata kamu yang ku anggap nyebelin

tapi gak bisa ku lupain

yang hitam yang putih ku cobain

yang tinggi yang pendek aku rasain

tapi kamu yang sedang-sedang saja

Diksi pada lirik lagu di atas terjadi perubahan makna pada klausa yang hitam yang putih kucobain, yang tinggi yang pendek aku rasain. Kata cobain dan rasain tersebut kurang enak didengar karena selain tidak baku, menunjukkan perilaku mencicipi hidangan. Maksud dari kata cobain pada lirik lagu tersebut adalah telah menjalani pengalaman dengan seseorang dalam hal asmara. Kata tersebut termasuk sarkasme karena sesuai dengan karakteristik sarkasme yaitu kurang enak didengar, olok-olok dan menyakiti hati. Dari uraian tersebut jelaslah bahwa diksi cobain kurang tepat digunakan pada lirik tersebut karena menyamakan sifat benda yaitu lidah dengan manusia sebgaai pelakunya. Pendidikan karakter yang hancur karena kata tersebut adalah nilai rasa, karsa, moral dan budi perkerti. Keempat indikator pada pendidikan karakter ini ditinjau dari segi baik buruknya sikap, tingkah laku ataupun mengenai perbuatan.

bikin aku pengen balikan

keenakan aku, aku keenakan

ketagihan sama kamu, ketagihan

Diksi pada lirik lagu di atas terjadi perubahan makna pada klausa keenakan aku keenakan, ketagihan sama kamu ketagihan. Diksi pada lirik lagu di atas terjadi perubahan makna pada klausa ketagihan, dan keenakan. Kata menggoda termasuk sarkasme karena sesuai dengan karakteristik sarkasme yaitu kurang enak didengar, olok-olok dan menyakiti hati. Hal ini sejalan dengan Sugono dkk (2008: 371) kata keenakan berarti kesenangan, kenyamanan, terlalu merasa enak, menjadi terbiasa (biasanya hal-hal yang kurang baik). Frasa tersebut kurang enak didengar karena menunjukkan perilaku mengajak berbuat sesuatu yang tidak baik. Dari uraian tersebut jelaslah bahwa diksi keenakan, ketagihan kurang tepat digunakan pada lirik tersebut. Pendidikan karakter yang hancur karena kata tersebut adalah nilai rasa, karsa, moral dan budi perkerti. Keempat indikator pada 
Jurnal Penelitian Bahasa dan Sastra Indonesia V2.i2 (61-71)

pendidikan karakter ini ditinjau dari segi baik buruknya sikap, tingkah laku ataupun mengenai perbuatan.

Judul lagu: Sisa Semalam

Penyanyi : Zaskia Gotik

aku kelangit sampai sembilan menggapai bintang bermesraan ku terlena na na aw aw aw dalam cinta ta ta ta masih melayang aku bagai terbang sisa semalam ku dibelai sayang masih terasa bersarang di dada sisa semalam ku dibuai cinta

Diksi pada lirik lagu di atas terjadi perubahan makna pada klausa masih melayang aku bagai terbang, sisa semalamku dibelai sayang, masih terasa bersarang di dada sisa semalam ku dibuai cinta. Kata tersebut kurang enak didengar karena menunjukkan perilaku seseorang sehabis bercinta. Klausa tersebut termasuk sarkasme karena sesuai dengan karakteristik sarkasme yaitu kurang enak didengar, dan bersifat olok-olok. Selain itu, klausa tersebut menunjukkan perilaku mengajak berbuat sesuatu yang tidak baik. Pendidikan karakter yang hancur karena kata tersebut adalah nilai rasa, karsa, moral dan budi perkerti. Keempat indikator pada pendidikan karakter ini ditinjau dari segi baik buruknya sikap, tingkah laku ataupun mengenai perbuatan.

masih berdebar tanganku gemetar sisa semalam kencangnya ah cetar

ku masih rasa hati ini rasa sisa semalam oh begitu indah semalam... melayang...

Diksi pada lirik lagu di atas terjadi perubahan makna pada klausa masih berdebar tanganku gemetar, sisa semalam kencangnya ah cetar. Klausa tersebut kurang tepat digunakan karena menunjukkan perilaku yang tidak baik. Hal ini ditunjukkan dengan frasa kencangnya ah cetar. Frasa tersebut termasuk sarkasme karena sesuai dengan karakteristik sarkasme yaitu kurang enak didengar, dan bersifat olok-olok. Hal ini sejalan dengan Sugono dkk (2008: 667) kata kencang berarti tegang, tidak kendur. Kencangnya ah cetar berarti suatu benda yang tegang, dan tidak kendur dilanjut dengan kata tidak baku yaitu cetar menunjukkan eskpresi berlebihan yang identik dengan kata sangat. Kata tersebut kurang tepat didengar karena menunjukkan perilaku yang tidak baik. Pendidikan karakter yang hancur karena kata tersebut adalah nilai rasa, karsa, moral dan budi perkerti. Keempat indikator pada pendidikan karakter ini ditinjau dari segi baik buruknya sikap, tingkah laku ataupun mengenai perbuatan.

Judul lagu: Berondong Tua

Penyanyi : Siti Badriah

ada berondong tua

tebar-tebar pesona

sukanya daun muda

Diksi pada lirik lagu di atas terjadi perubahan makna pada frasa berondong tua dan daun muda. Istilah berondong tua digunakan untuk menunjukkan seseorang yang sudah tua tetapi masih ingin berpenampilan seperti anak muda. Istilah daun muda digunakan untuk menunjukkan usia seseorang yang di bawah umur dan belum menikah. Frasa tersebut termasuk sarkasme karena sesuai dengan karakteristik sarkasme yaitu berupa sindiran pedas. Sindiran terhadap seseorang yang sudah tua tetapi masih suka dengan remaja, atau generasi muda. Frasa tersebut kurang cocok digunakan karena menunjukkan perilaku mengajak berbuat sesuatu yang tidak baik. Pendidikan karakter yang hancur karena frasa tersebut adalah nilai rasa, karsa, moral dan budi perkerti. Keempat indikator pada pendidikan karakter ini 
Jurnal Penelitian Bahasa dan Sastra Indonesia V2.i2 (61-71)

ditinjau dari segi baik buruknya sikap, tingkah laku ataupun mengenai perbuatan.

dia lupa usia

ada berondong tua

fangky habis gayanya

sukanya hura hura

hepi aja maunya

berondong berondong tua

jelalatan cari mangsa

keluar masuk lubang buaya

jadi santapan wanita wanita muda

Diksi pada lirik lagu di atas terjadi perubahan makna pada klausa jelalatan cari mangsa, keluar masuk lubang buaya, jadi santapan wanita-wanita muda. Klausa tersebut termasuk sarkasme karena sesuai dengan karakteristik sarkasme yaitu kurang enak didengar bersifat olok-olok, sindiran pedas dan menyakiti hati. Hal ini sejalan dengan Sugono dkk (2008: 574) kata jelalatan berarti melihat ke manamana dengan liar. Mangsa menurut Sugono dkk (2008: 874) berarti sasaran perbuatan jahat. Klausa tersebut kurang enak didengar karena menunjukkan perilaku yang tidak baik yaitu melihat orang lain dengan liar untuk mencari sasaran perbuatan jahat sehingga dimanfaatkan oleh wanita muda karena orang tua itu sudah sering bergaul atau berkelakar dengan wanita-wanita muda dalam konteks nakal. Dari uraian tersebut jelaslah bahwa klausa tersebut kurang tepat digunakan pada lirik lagu. Pendidikan karakter yang hancur karena kata tersebut adalah nilai rasa, karsa, moral dan budi perkerti. Keempat indikator pada pendidikan karakter ini ditinjau dari segi baik buruknya sikap, tingkah laku ataupun mengenai perbuatan.

Judul lagu: Gadis Bukan Perawan

Penyanyi : Linda Moy Moy

Aku hanyalah wanita biasa

Berbuat salah khilaf dan dosa

Karena cinta hatiku terlena

\section{Aku ternoda terbuai mesra}

Diksi pada lirik lagu di atas terjadi perubahan makna pada kata aku ternoda terbuai mesra. Kata tersebut kurang enak didengar karena menunjukkan perilaku yang secara langsung mengatakan bahwa si aku tidak suci lagi tapi sudah ternoda. Klausa tersebut termasuk sarkasme karena sesuai dengan karakteristik sarkasme yaitu kurang enak didengar, sindiran pedas dan menyakiti hati. Hal ini sejalan dengan Sugono dkk (2008: 965) kata noda berarti aib, cela, cacat. Ternoda berarti bercela, mendapat nama buruk. Kata tersebut kurang cocok digunakan karena menunjukkan perilaku buruk yang telah dilakukan. Dari uraian di atas jelaslah bahwa klausa tersebut kurang tepat digunakan pada lirik lagu. Pendidikan karakter yang hancur karena kata tersebut adalah nilai rasa, karsa, moral dan budi perkerti. Keempat indikator pada pendidikan karakter ini ditinjau dari segi baik buruknya sikap, tingkah laku ataupun mengenai perbuatan.

\section{Aku gadis tapi bukan perawan}

Diksi pada lirik lagu di atas terjadi perubahan makna pada klausa aku gadis tapi bukan perawan. Kata tersebut kurang enak didengar karena menunjukkan perilaku yang Kata menggoda termasuk sarkasme karena sesuai dengan karakteristik sarkasme yaitu kurang enak didengar, bersifat olok-olok, sindiran pedas dan menyakiti hati. Hal ini sejalan dengan Sugono dkk (2008: 403) kata gadis berarti anak perempuan yang belum kawin (perawan). Sugono (2008: 1053) kata perawan berarti anak perempuan yang sudah patut kawin, anak dara, perawan. Jadi, gadis identik atau sama dengan perawan dan begitu pula sebaliknya. Klausa gadis bukan perawan mempunyai arti yang berlawanan. Karena gadis pada lirik lagu tersebut berarti perempuan muda 
Jurnal Penelitian Bahasa dan Sastra Indonesia V2.i2 (61-71)

yang telah akhil baligh yang belum menikah, sedangkan perawan menunjukkan seorang gadis yang belum menikah. Jadi gadis bukan perawan berarti seorang perempuan yang belum menikah tetapi sudah pernah mengalami hal yang seharusnya dilakukan oleh perempuan yang sudah menikah. Dari uraian tersebut jelaslah bahwa diksi gadis bukan perawan kurang tepat digunakan pada lirik tersebut. Pendidikan karakter yang hancur karena kata tersebut adalah nilai rasa, karsa, moral dan budi perkerti. Keempat indikator pada pendidikan karakter ini ditinjau dari segi baik buruknya sikap, tingkah laku ataupun mengenai perbuatan.

\section{Keperawananku sudah hilang}

Gara-gara pacaran sering mesra-mesraan

Tapi untung gak hamil duluan

Makanya pacaran harus ada batasan

Makanya pacaran jangan sampai kelewatan

Diksi pada lirik lagu di atas terjadi
perubahan makna pada klausa keperawananku sudah hilang, gara-gara pacaran sering mesra-mesraan tapi untung nggak hamil duluan. Klausa tersebut termasuk sarkasme karena sesuai dengan karakteristik sarkasme yaitu kurang enak didengar, bersifat olok-olok dan menyakiti hati. Hal ini sejalan dengan Sugono dkk (2008: 478) kata hamil berarti mengandung janin dalam rahim karena sel telur dibuahi oleh sprematozoa. Kemudian Sugono dkk (2008: 994) pacar berarti teman lawan jenis yang tetap dan mempunyai hubungan berdasarkan cinta kasih. Klausa tersebut kurang cocok digunakan karena menunjukkan perilaku akibat perbuatan dengan lawan jenis yang dapat saja membuahkan janin dalam rahim, tetapi hal itu tidak terjadi yang ditunjukkan pada dua larik terakhir. Dari uraian di atas jelaslah bahwa klausa tersebut kurang tepat digunakan pada lirik lagu. Pendidikan karakter yang hancur karena kata tersebut adalah nilai rasa, karsa, moral dan budi perkerti. Keempat indikator pada pendidikan karakter ini ditinjau dari segi baik buruknya sikap, tingkah laku ataupun mengenai perbuatan.

Judul lagu: Buka Sikit Joss

Penyanyi : Juwita Bahar

Eh kenapa kamu kalau nonton dangdut sukanya bilang

Buka sikit joss

Diksi pada lirik lagu di atas terjadi perubahan makna pada klausa buka sikit joss. Klausa tersebut menunjukkan perilaku seseorang yang bersorak atau berteriak buka kepada orang di depannya. Frasa termasuk sarkasme karena sesuai dengan karakteristik sarkasme yaitu kurang enak didengar dan bersifat olokolok. Frasa tersebut menunjukkan perilaku yang tidak baik. Dari uraian tersebut jelaslah bahwa diksi buka sikit joss kurang tepat digunakan pada lirik lagu. Pendidikan karakter yang hancur karena kata tersebut adalah nilai rasa, karsa, moral dan budi perkerti. Keempat indikator pada pendidikan karakter ini ditinjau dari segi baik buruknya sikap, tingkah laku ataupun mengenai perbuatan.

Apa karena pakai rok mini jadi alasan

Sukanya abang ini intip-intip bodyku yang seksi

Sukanya abang ini intip-intipku pakai rok mini

Diksi pada lirik lagu di atas terjadi perubahan makna pada klausa sukanya abang ini intip-intip bodyku yang seksi, sukanya abang ini intip-intip ku pakai rok mini. Klausa tersebut menunjukkan perilaku seseorang yang tidak baik. Klausa tersebut termasuk sarkasme karena sesuai dengan karakteristik sarkasme yaitu kurang enak didengar, bersifat olok-olok dan menyakiti hati. Hal ini sejalan dengan Sugono dkk (2008: 916) frasa rok mini berarti rok berukuran pendek di atas lutut. Kata tersebut kurang cocok digunakan 
Jurnal Penelitian Bahasa dan Sastra Indonesia V2.i2 (61-71)

karena menunjukkan perilaku melihat sesuatu secara samar-samar atau sembunyi-sembunyi untuk melihat ke rok yang dipakai oleh seorang wanita. Dari uraian di atas jelaslah bahwa klausa tersebut kurang tepat digunakan pada lirik lagu. Pendidikan karakter yang hancur karena kata tersebut adalah nilai rasa, karsa, moral dan budi perkerti. Keempat indikator pada pendidikan karakter ini ditinjau dari segi baik buruknya sikap, tingkah laku ataupun mengenai perbuatan.

\section{SIMPULAN}

Dari hasil penelitian dan pembahasan, maka dapat disimpulkan bahwa perubahan makna pada jenis pengasaran terjadi akibat pilihan kata yang tidak tepat. Pada umumnya, diksi yang digunakan pada lirik lagu dangdut kekinian bersifat olok-olok, sindiran pedas, menyakiti hati dan kurang enak didengar. Pilihan kata tersebut ada yang secara langsung mendeskripsikan mengibaratkan menyamakan sifat objek tertentu dengan objek lainnya. Sarkasme yang ditimbulkan dari lirik lagu dangdut kekinian tidak hanya merusak estetika tetapi juga etika yang dapat berdampak pada kerusakan moral terutama pada anak-anak. Pendidikan karakter yang ditanamkan sejak dini dapat rusak seketika dengan lirik lagu dangdut kekinian tersebut.

\section{UCAPAN TERIMA KASIH}

Terima kasih kepada pihak-pihak yang telah membantu dalam penyelesaian penelitian ini. Pihak-pihak tersebut antara lain: kampus STKIP PGRI Sumatera Barat; Zulfadhli, S.S., M.A. dan Muhardis S.S., M.Hum.

\section{DAFTAR PUSTAKA}

Chaer, Abdul. 2009. Pengantar Semantik Bahasa Indonesia. Jakarta: Rineka Cipta.

Keraf, Gorys. 2010. Diksi Dan Gaya Bahasa. Jakarta: Gramedia Pustaka Utama.

Manaf, Ngusman Abdul. 2010. Semantik Bahasa Indonesia. Padang: Unp Press.

Moleong, Lexy J. 2002. Metodologi Penelitian Kualitatif. Bandung: Remaja Rosdakarya.

Parera, J.D. 2004. Teori Semantik. Jakarta: Erlangga.

Samani, Muchlas dan Hariyanto. 2012. Pendidikan Karakter. Bandung: Remaja Rosdakarya.

Sitaresmi, Nunung dan Mahmud Fasya. 2011. Pengantar Semantik Bahasa Indonesia. Bandung: UPI Press.

Sugono, dkk. 2008. Kamus Besar Bahasa Indonesia (Edisi Keempat). Jakarta: Gramedia.

Tarigan, Henry Guntur. 2009. Pengajaran Gaya Bahasa. Bandung: Angkasa.

Zubaedi. 2011. Desain Pendidkan Karakter. Jakarta: Kencana Prenada Media Group. 